\title{
Three Attempts at Inflation Forecasting in Pakistan
}

\author{
MADHAVI BOKIL and AXEL SCHIMMELPFENNIG ${ }^{1}$
}

\begin{abstract}
This paper presents three empirical approaches to forecasting inflation in Pakistan. The preferred approach is a leading indicators model in which broad money growth and private sector credit growth help forecast inflation. A univariate approach also yields reasonable forecasts, but seems less suited to capturing turning points. A vector autoregressive (VAR) model illustrates how monetary developments can be described by a Phillips-curve type relationship. We deal with potential parameter instability on account of fundamental changes in Pakistan's economic system by restricting our sample to more recent observations. Gregorian and Islamic calendar seasonality are addressed by using 12-month moving averages.
\end{abstract}

\section{INTRODUCTION}

Inflation forecasts can be important input for monetary policy formulation. For most central banks, inflation is at least one monetary policy objective. Given typical time lags, monetary policy needs to be concerned with future inflation rather than with current inflation levels. Inflation forecasts that link future inflation to current developments can bridge this gap. Some central banks have even adopted an inflation forecast target. However, this assumes that inflation forecasts are very reliable. Still, even in situations where structural relationships are less stable and data quality is still evolving, quantitative inflation forecasts can provide useful information on future developments that need to be combined with additional analysis going beyond econometrical relationships. This paper attempts to develop an inflation forecasting model for Pakistan.

Monetary policy in Pakistan is charged with three objectives. According to the State Bank of Pakistan's (SBP) July 2004 monetary policy statement (page 5), monetary policy "... will have to ensure that the current growth and investment momentum in the country is not impaired in any significant manner, export competitiveness is maintained while inflation is kept under control." The SBP has operationalized these objectives as quantitative targets. The inflation target for 2004/05 was 5 percent, though it has subsequently been raised to 7 percent. The SBP has also adopted the government's growth targets of 6.5 percent in 2004/05, increasing to 8 percent over the medium term. Lastly, the SBP tries to smooth excess exchange rate volatility, at times giving the impression of supporting certain psychological thresholds for the Pakistani rupee-

${ }^{1}$ Authors e-mail addressess: madhavi@ucsc.edu and aschimmelpfennig@imf.org. Madhavi Bokil was a summer intern at the IMF when this paper was initiated; she is currently at the University of California at Santa Cruz. Axel Schimmelpfennig is an economist at the Middle East and Central Asia Deparment of IMF. The authors would like to thank Ashfaque Khan, Jorge Canales-Kriljenko, Abdul Naseer, Milan Zavadjil, and participants at a MCD Economist Research Club Seminar for their valuable comments. 
U.S. dollar rate. More generally, the SBP looks at competitiveness when assessing the exchange rate. At times, these objectives can be conflicting and thus difficult to achieve simultaneously using only monetary policy instruments.

Data availability together with potential parameter instability are the main challenges to forecasting inflation. Pakistan's national accounts are compiled on an annual basis, so that only a few, mostly monetary variables, are available at high frequency and with short lags. In addition, we find several structural breaks in long time series reflecting fundamental policy framework changes that are difficult to model explicitly. We address these challenges by truncating our sample and including only recent observations that do not include severe structural breaks. In order to still have a reasonably large sample size, we use monthly data, which limits our choice of variables to monetary variables, and a manufacturing index that serves as a proxy for activity.

This paper presents three empirical approaches to forecasting inflation in Pakistan. The preferred approach is a leading indicators model (LIM) in which broad money and private sector credit growth lead inflation by more than six months. A vector autoregressive model (VAR) illustrates how monetary developments can be described by a Phillips-curve type relationship. A univariate approach (auto-regressive integrated moving average, ARIMA) seems less suited to capturing turning points. While far from perfect, the LIM may be helpful to inform monetary policy formulation.

The remainder of the paper is organized as follows. Section II briefly surveys literature on inflation forecasting and summarizes empirical work on inflation and money demand in Pakistan. Section III describes the data and illustrates the potential parameter instability based on a simple money demand function. Section IV presents the three forecasting models, and Section V concludes.

\section{A Selective LoOK AT THE Literature}

\section{A. Determinants of Inflation}

There is a large and growing literature on inflation forecasting in emerging market economies. Similar to the findings for advanced economies, changes in money growth, nominal exchange rates, price of imports, inflation expectations, and exogeneous supply shocks, especially to oil and food prices, are identified as the main determinants of inflation in emerging market economies. ${ }^{2}$ This is consistent with theoretical work that views inflation to be a monetary phenomenon in the long run when prices and wages are flexible and output and employment are always at their natural rates, but in the short run, models inflation as being also driven by real and nominal shocks that affect aggregate demand relative to aggregate supply.

There are several theoretical starting points for empirical inflation forecasting models. The Phillips curve has been used extensively in inflation forecasting, linking inflation to some measure of real economic activity such as the unemployment rate. When forecasting is the objective, Stock and Watson (1989) show that going beyond a single model such as the Phillips curve and including a wide set of potential explanatory variables leads to a better model in terms of forecast accuracy. Monetary variables, e.g.,

${ }^{2}$ For example, Chauvet (2000) and International Monetary Fund (2001) for Brazil, Leigh and Rossi (2002) for Turkey, Sun (2004) for Thailand, Coe and Mc Dermott (1997), Simone (2000), and Bailliu, Garcés, and Kruger (2003). 
based on a money demand function, can serve as additional explanatory variables in an inflation forecasting model. Monatization of the fiscal deficit can also contribute to inflation, though Fischer, Sahay, and Végh (2002) find a strong relationship between fiscal deficits and inflation only for high inflation countries or during high inflation episodes. In open economies, inflation can result from movements in the nominal exchange rates. Finally, inflation expectations and their formation can impact inflation through price-wage spirals or inertia. ${ }^{3}$

\section{B. Empirical Studies for Pakistan}

A large number of empirical studies is available that looks at inflation and monetary policy relationships in Pakistan. Some studies are based on samples going back as far as the 1950s, but most start in 1972, using either annual or constructed quarterly data. Most studies employ either cointegration techniques or estimate vector autoregressive models (often in first differences). All studies are in the business of model building and none attempts to use their results for forecasting. Table 1 provides a survey of the literature.

Most empirical studies find standard economic relationships to hold. Estimates of money demand functions mostly find money demand to be determined by measures of opportunity costs and activity (e.g., Tariq and others, 1997). Likewise, inflation is influenced by changes in money supply, interest rates, measures of aggregate demand or output, and import prices (e.g., Ahmad and Ali, 1999a). While most studies find such relationships to hold in a cointegration framework, a few fail to find cointegration which could suggest structural breaks in particular samples (e.g., Shamsuddin and Holmes, 1997). There seems to be no or only little exchange rate pass-through to domestic prices (e.g., Choudhri and Khan, 2002).

\section{DATA AND SAMPLE}

Three main challenges to developing a forecasting model arise with respect to the data. First, ongoing changes in Pakistan's financial system such as financial deepening imply that simple standard relationships such as money demand functions may not be stable at the end of the sample period. Second, only a few, mostly monetary, variables are available on a monthly or quarterly basis. ${ }^{4}$ Third, Pakistan's data is not only subject to Gregorian calendar effects, but also to Islamic calendar effects. ${ }^{5}$ Our choice of variables and their transformations are largely motivated by these challenges.

The database includes mostly monetary and financial data available at monthly frequency. We restrict the analysis to monthly data because this is available with much shorter lags and thus more suitable for a continuous forecasting exercise. Moreover, this also gives us a sufficient number of observations and thus degrees of freedom even though we do not extend our sample before 1998. However, restricting ourselves to monthly data implies that we cannot use variables such as GDP because national accounts are compiled only on a fiscal year basis. As such, data is restricted to monetary

\footnotetext{
${ }^{3}$ Other studies have looked at the term structure (e.g., Estrella and Mishkin, 1997) or asset prices (e.g., Goodhart and Hofman, 2000) as variables that help forecast inflation.

${ }^{4} \mathrm{GDP}$, for example, is available only annually, though quarterly national accounts are under construction.

${ }^{5}$ Prices tend to increase during Ramadan and the Eids (religious holidays).
} 
aggregates, interest rates, the exchange rate, and inflation. In addition, we use the monthly large-scale manufacturing index to proxy activity. Table 2 presents descriptive statistics for the core variables in our database.

\section{A. Seasonality and Stationarity}

We address seasonality by using 12-month moving averages. Using average annual inflation as well as 12-month averages for possible regressors in the VAR and the LIM smoothes out calendar year effects. In addition, averaging should also smooth out Islamic calendar effects, except for the rare case where, for example, two Eids fell into one calendar year. ${ }^{6}$ For the ARIMA, we also test whether inclusion of Islamic calendar dummies improves the estimated model.

Using 12-month moving averages has other advantages. Inflation targets are typically set for average annual inflation (or core inflation), though this may be combined with a path for year-on-year or month-on-month inflation. In this sense, the forecast of average annual inflation is directly applicable to the policy discussion without having to convert a forecast trajectory for year-on-year inflation into an annual average inflation. In addition, 12-month moving averages are likely to be less volatile than monthly observations that can be subject to temporary erratic shocks.

Most core variables in the database are nonstationary in levels (Table 3). In our sample range, the consumer price index (CPI), broad money, credit to the private sector, the six-month treasury-bill rate and the output gap ${ }^{7}$ are integrated of order one based on augmented Dickey-Fuller (ADF) tests. However, reserve money and the large scale manufacturing index are stationary. Inflation is found to be integrated of order two by the ADF test. While this is not unusual, it seems somewhat at odds with the finding that the CPI is integrated of order one. Moreover, a graphical inspection of the inflation series casts some doubt on this result as does the Phillips-Perron test. Private sector credit growth is found to be stationary by both tests which is also surprising given its high correlation with broad money growth. When interpreting these results it is important to bear in mind that tests for nonstationarity are biased toward nonrejection in small samples.

\section{B. Sample and Structural Breaks}

We mostly restrict the sample to July 1998 onwards. This starting point was chosen to exclude observations before the 1998/99 crisis after which the exchange rate was liberalized substantially and financial policies were targeted at macroeconomic stabilization. A casual look at the data supports this cut off date as inflation appears to be much more stable since the crisis. Truncating the sample in 1998 has the added advantage that the recent fundamental changes in the financial system would be better reflected in the estimated coefficients which should contribute to better forecasts. However, nonconstant coefficients remain a problem for at least one of our approaches. At the time

\footnotetext{
${ }^{6}$ Several standard techniques are available to address Gregorian calendar seasonality. However, only little work has been done to address Islamic calendar effects that cannot be controlled for by standard techniques which are calendar year-based because the Islamic year is shorter than the calendar year. A notable exceptions is Riazuddin and Khan, 2002.

${ }^{7}$ We calculate the output gap as the difference of the large scale manufacturing index from its long-run trend in percent of the trend.
} 
of estimation, the latest available observation was December 2004 for some variables which leaves a fairly short sample.

Pakistan has undergone several distinct policy framework changes over the last three decades. The Pakistani rupee was fixed against the U.S. dollar in the 1970s and was floated in 1982. Throughout the 1980s and 1990s, the Pakistani rupee depreciated against the U.S. dollar, peaking during the 1998/99 debt crisis. Since then, the SBP has pursued a managed float policy. Monetary policy relied on credit plans to the public and private sector in the 1970s and 1980s. Interest-free banking was partially introduced in 1981 and interest-bearing deposits of banks were replaced by a profit and loss sharing system in 1985. In 1989, Pakistan started on a financial sector reform program that involved interest rate liberalization, reduction of credit controls, and strengthening the supervisory framework. During the 1989/99 debt crisis, the SBP had to temporarily freeze foreign currency deposits and imposed exchange controls that were subsequently lifted again. Financial sector reforms gained momentum after the debt crisis. Today, the SBP uses t-bill auctions as the main monetary policy instrument. The SBP also operates a discount window and carries out open market operations as needed for liquidity management purposes and to support the general monetary policy direction. The SBP does not publish a quantitative inflation forecast, but the semiannual monetary policy statement includes an inflation target and discusses prospects for achieving the target. Ongoing financial deepening changes the environment for monetary policy. The SBP has moved away from targeting monetary aggregates such as reserve money and net domestic assets (NDA). In the past few years, NDA targets agreed under the IMF program were not effective in controlling reserve money growth because of the strong net foreign asset accumulation that continued to outperform projections. Instead, the SBP has relied increasingly on short-term interest rates to achieve its objectives. With steady improvements in financial intermediation and continued financial deepening, the credit channel should become more effective, strengthening short-term interest rates as the main policy instruments. Our finding below that private sector credit growth is a good leading indicator for inflation is evidence that the credit channel is part of the monetary transmission mechanism in Pakistan.

\section{A casual look at monetary and inflation developments indicate that standard} relationships may not always hold, in particular for more recent observations (Figures 1 and 2). Since 2000/01 (July-June), broad money, credit to the private sector, as well as currency in circulation have grown much faster than nominal GDP. At the same time, inflation has dropped from its average of above 10 percent in the early $1990 \mathrm{~s}$ to below 5 percent in 2002/03. Though, more recently, inflation has increased again to about 7 percent at the end of 2004. One reason for these developments is likely to be the process of financial deepening that has occurred since 1999. Reforms have substantially strengthened the banking sector and have lead to large improvements in financial intermediation (cf. International Monetary Fund, 2004). A closer inspection of the CPI inflation time series suggests that a structural break may have occurred somewhere around the 1998/99 debt crisis.

Estimating a simple money demand function with annual data from 1975 through 2004 illustrates parameter instability. As a preliminary exercise, we estimate a money 
demand function based on the quantity equation.

$\ln P=-\ln v+\beta_{1} \ln M-\beta_{2} \ln Y$

where $P$ is the CPI, $v$ the velocity, $M$ broad money, and $Y$ real GDP. For this exercise, we use annual data from the IMF's International Financial Statistics database from 1975 through 2004. All coefficients carry the expected sign: the constant, that is the log of velocity is negative, an increase in broad money raises the CPI, and an increase in real GDP reduces the CPI (Table 4). ${ }^{8}$ However, the coefficient on real GDP is not significant. Calculating recursive estimates for the coefficients clearly exhibits parameter instability (Figure 3). In the case of real GDP, the coefficient even switches signs from positive to negative. The recursive coefficients suggest two break points. The first one occurs around 1992 when Pakistan floated the Pakistani rupee, and the second one seems to occur around 1999 when financial policies were directed toward macroeconomic stabilization after the 1998/99 debt crisis.

\section{These results are confirmed when using monthly data from 1995 through 2004 . $^{9}$}

Instead of real GDP, we use a manufacturing index available on a monthly basis. ${ }^{10}$ Again, all coefficients carry the expected sign, and in this case, all are significant at all standard levels (Table 5). ${ }^{11}$ The recursive coefficients point to structural breaks around 1997 and again in 1999/2000; there is also a sign switch at the beginning of the sample period for the manufacturing index (Figure 4). Maybe most interestingly, the estimate of the velocity increases from around 0.004 in 1996 to 0.08 in 2004 which would be consistent with financial deepening.

For our purposes of developing an inflation forecasting model, we try to overcome this parameter instability by restricting our sample to the period of 1998 onwards. The above parameter instability could be addressed in two ways. We could attempt to explicitly model the structural changes such as financial deepening. However, given the scarcity of available data, we are doubtful whether this can be done sufficiently well to yield a good forecasting model. Therefore, we choose to focus our empirical work on more recent episodes that are not subject to distinct structural breaks. This has to be balanced by the need to have a sufficiently large sample for the estimation. Based on some initial and preliminary work, we restrict our sample to observations from July 1998 onwards.

\footnotetext{
${ }^{8}$ Given that all time series are integrated of order one, the least squares regression should be viewed as the first stage of the Engle/Granger approach. Using the standard cointegration test based on the regression residuals, the null hypothesis of cointegration is not rejected.

${ }^{9}$ All variables are 12-month moving averages to account for Gregorian and Islamic calendar seasonality.

${ }^{10}$ The correlation coefficient between the annual manufacturing index and real GDP is 0.97 which suggests that a 12-month moving average of the manufacturing index should be a reasonable proxy for monthly GDP.

${ }^{11}$ The null hypothesis of cointegration is not rejected.
} 


\section{Three Forecasting ApProaches}

We use three empirical approaches to forecasting inflation. As a benchmark, we estimate a univariate ARIMA model. Next, we use a VAR model that includes several variables based on an economic model. And finally, we use a LIM, which less concerned with mirroring an economic model. We find the LIM to be best suited for forecasting in terms of statistical properties and measures of forecast accuracy. However, once longer time-series become available, we believe that an economic model-based VAR could allow more in-depth policy analysis.

\section{A. A Univariate Forecasting Model}

In the simplest form, inflation can be modeled as an ARIMA process. We determine the optimal lag length according to the Box-Jenkins methodology, significance tests, and statistics measuring the forecast quality such as the root square mean error. Even though the CPI itself is integrated of order 1, average annual CPI inflation also appears to be integrated of order 1 . Therefore, we differentiate average annual inflation once. We have also experimented with ARMAs for average annual inflation and 12-month inflation, but the results did not improve upon what is presented here.

We estimate the following ARIMA(p,1,q) model

$$
\Delta \dot{P}_{t}=\alpha_{0}+\sum_{i=1}^{p} \alpha_{i} \Delta \dot{P}_{t-i}+\sum_{j=0}^{q} \gamma_{i} u_{t-i}
$$

where $\dot{P}$ denotes average annual CPI inflation and $u$ denotes a white noise error term.

The best specification is an ARIMA $(5,1,1)$ model which delivers reasonable predictions. The autocorrelation function slowly dampens and becomes insignificant at lag 6, while the partial autocorrelation function breaks off after lag 1 (Figure 5). This suggests and ARIMA $(6,1,0)$. However, looking at information criteria, root mean square error and similar statistics suggests an $\operatorname{ARIMA}(5,1,1)$ (Table 6). ${ }^{12}$ Reestimating the $\operatorname{ARIMA}(5,1,1)$ for a reduced sample through June 2004 allows us to forecast for the remainder of 2004 and compare the forecast to the actual developments (Figure 6). The forecast has inflation increasing during July-December 2004, but not as fast as actual inflation did increase. As such, actual inflation is consistently above the 2-sigma band. Still, while the forecast fails to anticipate the extent by which inflation increased, it does anticipate the increase itself. In earlier work for a shorter sample, ARIMA models had difficulties anticipating turning points-unsurprisingly as they do not explicitly model exogenous shocks.

Including Islamic calendar dummies in the ARIMA(5,1,1) does not improve the forecast quality. We use four Islamic calendar dummies constructed by Riazuddin and Khan (2002).${ }^{13}$ The four dummies control for effects related to Muharram, Ramashan, Shawal, and Thul Hujja and take on values between zero and one depending on how many days of a particular holiday fall into a month. Unfortunately, including these

${ }^{12}$ Doing a wider search for the best lag structure based on the information criteria, root mean squared error and other related statistics suggests an $\operatorname{ARIMA}(11,1,11)$ as the best model. However, in terms of actual forecast, this specification does no better than the $\operatorname{ARIMA}(5,1,1)$ and we thus prefer the more parsimonious specification.

${ }^{13}$ We thank the authors who kindly provided this data for our work. 
dummies does not improve the model's forecast quality (Figure 7), and the dummies themselves are estimated as insignificant at the 5 percent level (Table 7). We interpret these results to mean that using 12-months averages sufficiently addresses Islamic calendar effects.

\section{B. An Unrestricted Vector Autoregressive Model} A VAR allows a more model-based approach that should be better able to identify shocks that may trigger turning points in inflation. With nonstationary variables, the VAR can be specified as a vector error correction model in levels that separates long-run and short-run relationships. However, we failed to find cointegration in various specifications which is likely to reflect the fairly short sample span that does not provide sufficient information on long-run relations as well as the structural changes taking place in the financial system. Therefore, we specify a VAR in first differences that describes only short-run relationships. Parameter restrictions would be required to make the VAR truly model-based. However, for now, we have only estimated an unrestricted VAR. The VAR's lag length is selected based on standard information criteria and tests for normality of the error terms; the information criteria suggest a lag length of one, but we set the lag length at three to ensure that the residuals are white noise. ${ }^{14}$

The widely used Phillips curve provides the theoretical starting point. We estimate a three-dimensional VAR that includes the inflation rate, the output gap, and the real interest rate. We define the real interest rate as the difference between the 3-month t-bill rate and expected inflation where inflation expectations are based on a simple ARMA model. Alternatively, we used the nominal t- bill rate which resulted in the fairly common finding of a price puzzle where an unexpected tightening in monetary policy leads to an increase rather than a decrease in the price level. Introducing a forward looking variable addresses this theoretical inconsistency (e.g. Brissimis and Magginas, 2004), in our case this is the expected real interest rate. ${ }^{15}$

We need to further curtail the sample for the VAR estimation. When starting the sample in July 1998, we cannot identify a meaningful VAR specification that satisfies standard statistical criteria. A look at a time series chart for inflation and the output gap reveals why this might be the case (Figure 8). The typical relationship where a closing output gap puts upward pressure on inflation only emerges after July 2001. Therefore, we start the sample for the VAR estimation only in July 2001 which leads to more interesting results. However, the very small sample size severely limits the quality of these results. The estimation results are shaky, but provide some insights. Our preferred specification is a VAR including inflation, a real interest rate (defined as the 3-month tbill rate less expected inflation from an ARMA model), and the output gap. In this specification, inflation is low when the output gap is large (negative) or when the real interest rate is high (Table 8). However, there is no feedback between output gap or real

\footnotetext{
${ }^{14}$ Specifically, we relied on the Schwartz information criterion, the Akaike information criterion and the Hannan-Quinn information criterion to determine the lag-length.

${ }^{15}$ See Giordani (2004) and Balke and Emery (1994) for a discussion of the price puzzle finding.
} 
interest rate in either direction. ${ }^{16}$ The estimated output gap equation does not fit the data well. Reestimating the model for a reduced sample through March 2004 and comparing the forecast with actual data, shows that the VAR forecast does not capture the accelerating trend of inflation, though actual inflation is within the wide 2-sigma band (Figure 9).

As typical economic relationships are firming up in the data, the VAR approach should become a useful tool to forecast and analyze inflation trends. At present, not enough data is available to estimate a structural VAR with sufficient precision. Moreover, structural changes in the financial system result in nonconstant coefficients which make forecasting problematic. However, after 2001, Phillips curve-type relations are found in the data. If these relations were to firm up going forward, a structural VAR that reflects an economic model should provide a powerful tool for forecasting inflation and analyzing monetary policy.

\section{Leading Indicators Model}

The leading indicators approach searches for variables that co-move with the variable to be forecasted without imposing a model structure. Leading indicators do not necessarily need to be causal factors of the target variable as part of an economic model, though this would presumably strengthen one's confidence in a forecasting model (e.g., Marcellino, 2004, and Stock and Watson, 1989 and 1999). We use the general-tospecific algorithm in PcGets to narrow down the set of possible leading indicators from our full dataset and then use the same criteria of forecast accuracy as for the ARIMA to arrive at a final specification (see Hendry and Krolzig, 2004). We require indicators to lead inflation by at least 6 months and allow for leads up to 12 months.

Private sector credit growth and broad money growth are leading indicators of inflation (Table 9). The general model includes the following variables that could be leading indicators for inflation: wholesale-price index inflation, time-varying intercept, and slope coefficient for the yield curve, the spread between 12-month and 3-month t-bill rates, large-scale manufacturing index growth, broad money growth, reserve money growth, private sector credit growth, change in the nominal effective exchange rate, tax revenue growth, and the 6-month t-bill rate. Of these, only private sector credit growth and lags of inflation remain in the reduced specification (Model 1). We also show specifications that include broad money growth as one might expect a relationship between broad money growth and inflation. The best specification here is model 3 which includes lags of broad money growth and private sector credit growth in addition to lags of inflation. Both specifications are consistent with a monetary transmission mechanism that works through the credit channel.

The LIMs' exhibit a good ex-post forecast quality. Reestimating the LIMs through May 2004 and forecasting the remainder of 2004 allows a comparison of the models' forecast with actual developments (Figure 10). The ex-post forecast based on Model 1 (private sector credit growth) seems a bit closer to actual developments than the ex-post

${ }^{16}$ This can also be seen from impulse-response functions based on a Cholesky decomposition. The ordering of the variables does not matter for this result as the off-diagonal elements of the correlation matrix are close to zero. 
forecast based on Model 3 (private sector credit growth and broad money growth). However, the ex-post forecast based on Model 3 has a lower standard error.

The LIMs do not suffer from parameter instability. Figures 11 and 12 show recursive coefficient estimates for Model 1 and 3. In both cases, the coefficient estimates do not fluctuate much once the sample has reached a certain size, and the coefficient estimate for the full sample remains mostly in the 2-sigma band around the recursive coefficient estimates.

The leading indicators models yield a fairly accurate forecast, but are not firmly grounded in an economic model. By construction, the approach picks leading indicators that yield a high forecast accuracy at the current juncture. Moreover, higher broad money growth and higher private sector credit growth being associated with higher inflation seems plausible from an economic point of view. However, the choice of leading indicators may change over time, so that the forecasting model may not be stable. As such, periodic respecification and reestimating would be required.

\section{SUMmarY AND CONCLUSIONS}

Pakistan's economic data permits quantitative forecasts of inflation. High frequency data for Pakistan is largely restricted to monetary data. Only few real sector variables are available at a sub-annual basis. The monthly large-scale manufacturing index, which is correlated with real GDP, is a notable exception. Models that build on longer time series going back before the 1998/99 debt crisis suffer from parameter instability associated with structural and economic regime changes in Pakistan. Nonetheless, we found that the available monthly data from 1998 onward is sufficiently rich to allow inflation forecasting.

The leading indicators approach seems most suited for inflation forecasting at this time. We presented two variants of a leading indicator model that performed well in expost forecasts and could be related back to economic transmission channels. The univariate approach also resulted in a fairly acceptable forecasting model, though the ARIMA's forecasting accuracy was much less than the LIMs'. The model-based VAR approach yielded the least satisfactory forecasting model, but provided some first glances at the evolving monetary transmission mechanism. Given the ease of computing, it is possible to simultaneously use both LIM variants and the ARIMA for forecasting. The LIM based on broad money growth and private sector credit growth as well as lags in inflation may be a natural candidate for the "central" forecast since it almost nests the LIM based on private sector credit growth and lags in inflation as well as the ARIMA. A forecasting model based on economic theory would be useful to analyze and simulate monetary policy. Our preferred forecasting models are largely driven by statistical properties and less by economic intuition. As such, there is limited scope to use these models to analyze monetary policy in more detail. For example, it is strictly speaking not possible to invert the leading indicators model to derive by how much monetary growth would have to be reduced to achieve a certain inflation target. As economic relationships in Pakistan firm up, a structural VAR approach to inflation forecasting should become feasible, which would yield a richer forecast that will also allow an analysis of the impact of monetary policy instruments.

The models presented here can be developed further. In part, this will require longer time series, but also some stabilization in the rapidly developing financial system to 
ensure parameter stability. Given the data limitations, our econometric techniques were also constrained, and we look forward to future refinements. In the meantime, we can put our LIM-based forecasts to the test of time.

Fairly simple forecasting models can still be quite powerful. Looking beyond

Pakistan, our paper suggests that it does not necessarily take a lot of data or long timeseries to come up with a decent forecasting model. In many cases, it is not possible to explicitly model exogenous changes that lead to parameter instability because there is not enough data or the required model would be too complex for forecasting purposes.

Restricting the sample to more recent observations is one alternative that can work. Of course, this comes at the cost of loosing information (and degrees of freedom). Moreover, this may require frequent respecification of the forecasting model if the economy continues to undergo changes. The leading indicators approach combined with the general-to-specific algorithm in PcGets lend themselves to the application in data scarce environments. The algorithm allows to work through a large number of specifications do not necessarily have to be nested in one single equation if this is not possible because of a small sample size.

Table 2. Pakistan: Descriptive Statistics

(Average annual change in percent unless otherwise indicated)

\begin{tabular}{|c|c|c|c|c|c|}
\hline & Mean & Median & Minimum & Maximum & $\begin{array}{c}\text { Standard } \\
\text { Deviation }\end{array}$ \\
\hline Inflation & 4.2 & 3.9 & 2.4 & 7.4 & 1.4 \\
\hline Broad money & 12.5 & 12.2 & 4.3 & 19.2 & 4.8 \\
\hline Reserve money & 12.5 & 12.7 & 8.5 & 17.5 & 2.5 \\
\hline Credit to the private sector & 12.4 & 12.3 & 1.7 & 30.4 & 8.1 \\
\hline 6-months treasury bill rate & 7.6 & 7.6 & 1.2 & 15.6 & 4.1 \\
\hline Large-scale manufacturing index & 7.8 & 6.3 & -21.1 & 47.0 & 12.2 \\
\hline Output gap 1/ & -0.4 & -1.9 & -6.7 & 10.7 & 4.1 \\
\hline
\end{tabular}

Source: Pakistani authorities; and own calculations.

1/ Defined as the deviation of the large-scale manufacturing index from its trend in percent of the trend.

Table 3. Pakistan: Test of Nonstationarity of Core Variables

\begin{tabular}{lcc}
\hline \multirow{2}{*}{ Level } & $\begin{array}{c}\text { First } \\
\text { Difference }\end{array}$ & $\begin{array}{c}\text { Critical } \\
\text { Value 1/ }\end{array}$ \\
\hline
\end{tabular}

Augmented Dickey Fuller Test 
CPI 2/

Inflation 2/

Broad money 2/

Credit to the private sector $2 /$

Large scale manufacturing index 2/

Output gap 2/

CPI 2/

Inflation 3/

Broad money 3/

Credit to the private sector $3 /$

Large scale manufacturing index 2/

Output gap 2/
$1.844 \quad-6.674$

$-2.255$

$-1.872$

$-4.214$

$-4.296$

$-8.582$
$-2.900$

$-2.900$

$-2.900$

$-2.900$

$-2.900$

$-2.900$

\section{Phillips Perron Test}

$\begin{array}{rrr}1.715 & -6.674 & -2.900 \\ -0.510 & -2.328 & -1.945 \\ -0.164 & -1.946 & -1.945 \\ 0.651 & -1.555 & -1.945 \\ -4.422 & & -2.902 \\ -8.608 & & -2.902\end{array}$

Source: Pakistani authorities; and own calculations.

1/ Critical value at the 5 percent significant level as provided by Eviews.

2/ Model includes interept.

3/ Model without interept. 
Table 4. Pakistan: Regression Results for a Money Demand Function with Annual Data

Dependent variable

Sample

Observations

Adjusted R-squared

Durbin-Watson

F-statistic

Engle-Granger test 1/

Statistic

Critical value
Log CPI inflation

1975 to 2004
30

0.99

0.43

$1,125.68$

$-1.76$

$-3.74$

\begin{tabular}{lrrr} 
& & & \multicolumn{2}{c}{ Coefficient } & & \\
\cline { 2 - 3 } Constant & -3.46 & -8.277996 \\
Log M2 & 0.63 & 6.065496 \\
Log Real GDP & -0.18 & -0.63925 \\
\hline
\end{tabular}

Sources: International Financial Statistics; and own calculations.

1/ Test for cointegration based on regression residuals. See Davidson/MacKinnon (1993). 
Table 5. Pakistan: Regression Results for a Money Demand Function with Monthly Data

Dependent variable

Sample

Observations

Adjusted R-squared

Durbin-Watson

F-statistic

Engle-Granger test 1/

Statistic

Critical value
Log CPI inflation

1995:04 to 2004:07
112

0.98

0.17

$2,336.55$

$-3.53$

$-3.74$

\begin{tabular}{|c|c|c|}
\hline & Coefficient & $\mathrm{t}$-Statistic \\
\hline Constant & -2.44 & -23.27 \\
\hline $\log M 2$ & 0.91 & 33.43 \\
\hline Log Manufacturing Index & -1.16 & -17.49 \\
\hline
\end{tabular}

Sources: International Financial Statistics; and own calculations.

1/ Test for cointegration based on regression residuals. See Davidson/MacKinnon (1993). 
Table 7. Pakistan: Estimation Results for the ARIMA(5,1,1)

\begin{tabular}{|c|c|c|c|c|}
\hline $\begin{array}{l}\text { Dependent variable } \\
\text { Sample }\end{array}$ & \multicolumn{2}{|c|}{ Log CPI inflation } & \multicolumn{2}{|c|}{ Log CPI inflation } \\
\hline Observations & & 72 & & 72 \\
\hline Adjusted R-squared & & 0.83 & & 0.83 \\
\hline Durbin-Watson & & 1.99 & & 1.99 \\
\hline \multirow[t]{2}{*}{ F-statistic } & & 60.61 & & 36.53 \\
\hline & Coefficient & $\mathrm{t}$-Statistic & Coefficient & $\mathrm{t}$-Statistic \\
\hline Constant & 0.00 & 0.01 & -0.02 & -0.23 \\
\hline $\mathrm{AR}(1)$ & 0.09 & 0.73 & 0.12 & 0.91 \\
\hline $\operatorname{AR}(2)$ & 0.80 & 6.22 & 0.79 & 6.05 \\
\hline $\operatorname{AR}(3)$ & 0.27 & 1.72 & 0.27 & 1.73 \\
\hline $\operatorname{AR}(4)$ & -0.22 & -1.73 & -0.23 & -1.79 \\
\hline $\operatorname{AR}(5)$ & -0.24 & -1.80 & -0.26 & -1.92 \\
\hline $\operatorname{MA}(1)$ & 0.96 & 42.90 & 0.96 & 39.17 \\
\hline \multicolumn{5}{|l|}{ Dummy for } \\
\hline Muharram & & & 0.03 & 0.66 \\
\hline \multicolumn{5}{|l|}{ Dummy for } \\
\hline Ramashan & & & 0.02 & 0.58 \\
\hline Dummy for Shawal & & & 0.08 & 1.88 \\
\hline \multicolumn{5}{|l|}{ Dummy for Thul } \\
\hline Hujja & & & 0.00 & -0.01 \\
\hline
\end{tabular}

Sources: International Financial Statistics; and own calculations. 
Table 8. Pakistan: VAR Regression Results

\begin{tabular}{|c|c|c|c|c|c|c|}
\hline & \multicolumn{2}{|c|}{ Inflation 1/ } & \multicolumn{2}{|c|}{ Real interest rate $2 /$} & \multicolumn{2}{|c|}{ Output gap } \\
\hline & Coef. & t-stat. & Coef. & t-stat. & Coef. & t-stat. \\
\hline Constant & -0.0003 & -0.8169 & -0.0041 & -1.4852 & -0.0061 & -0.9759 \\
\hline \multicolumn{7}{|l|}{ Inflation 1/ } \\
\hline Lag 1 & 0.5214 & 1.9480 & -0.0113 & -0.0949 & -0.0004 & -0.0304 \\
\hline Lag 2 & 0.1801 & 0.5766 & -0.1692 & -1.2216 & -0.0136 & -0.8003 \\
\hline Lag 3 & -0.1076 & -0.4780 & 0.1871 & 1.8754 & 0.0020 & 0.1605 \\
\hline \multicolumn{7}{|l|}{ Real interest rate $2 /$} \\
\hline Lag 1 & -0.6722 & -1.6405 & 0.6308 & 3.4724 & 0.0086 & 0.3888 \\
\hline Lag 2 & 0.1086 & 0.2453 & -0.0169 & -0.0863 & -0.0326 & -1.3566 \\
\hline Lag 3 & 0.1000 & 0.2456 & 0.2431 & 1.3460 & -0.0030 & -0.1360 \\
\hline \multicolumn{7}{|l|}{ Output gap } \\
\hline Lag 1 & 1.4412 & 0.3830 & 0.5388 & 0.3229 & 0.2053 & 1.0059 \\
\hline Lag 2 & 8.9753 & 2.5371 & -1.2028 & -0.7669 & -0.3285 & -1.7127 \\
\hline Lag 3 & 5.9956 & 1.3974 & 2.1870 & 1.1497 & 0.1175 & 0.5049 \\
\hline Adjusted R-square & \multicolumn{2}{|c|}{0.75} & \multicolumn{2}{|c|}{0.80} & \multicolumn{2}{|c|}{-0.05} \\
\hline F Statistic & \multicolumn{2}{|c|}{11.62} & \multicolumn{2}{|c|}{15.12} & \multicolumn{2}{|c|}{0.82} \\
\hline
\end{tabular}

Sources: Pakistani authorities; and own estimates.

1/ Annual average inflation.

$2 /$ The real interest rate is defined as the nominal 3-month t-bill rate less expected inflation, where inflation expectations are based on an ARMA model. 
Table 9. Pakistan: Leading Indicators Model Regression Results

\begin{tabular}{|c|c|c|c|c|c|c|c|c|}
\hline \multirow[b]{2}{*}{ Observations } & \multicolumn{2}{|c|}{ Model 1} & \multicolumn{2}{|c|}{ Model 2} & \multicolumn{2}{|c|}{ Model 3} & \multicolumn{2}{|c|}{ Model 4} \\
\hline & & 73 & & 72 & & 72 & & 76 \\
\hline Adjusted R-squared & & 0.995 & & 0.996 & & 0.996 & & 0.996 \\
\hline F-statistic & & $2,555.1$ & & 881.6 & & $3,560.4$ & & $3,412.3$ \\
\hline Akaike Information Criterion & & -1.935 & & -1.967 & & -2.136 & & -1.913 \\
\hline Schwarz Information Criterion & & -1.716 & & -1.303 & & -1.947 & & -1.729 \\
\hline Root Mean Squared Error & & 0.397 & & 0.358 & & 0.388 & & 1.409 \\
\hline Mean Absolute Error & & 0.350 & & 0.280 & & 0.358 & & 1.259 \\
\hline \multirow[t]{2}{*}{ Mean Absolute Percentage Error } & & 5.662 & & 4.300 & & 5.834 & & 18.941 \\
\hline & Coefficient & t-Statistic & Coefficient & t-Statistic & Coefficient & t-Statistic & Coefficient & t-Statistic \\
\hline Constant & 0.111 & 2.813 & -0.069 & -0.585 & -0.182 & -2.638 & 0.086 & 2.082 \\
\hline \multicolumn{9}{|l|}{ Inflation } \\
\hline Lagged 1 month & 1.772 & 14.949 & 1.680 & 10.272 & 1.508 & 16.025 & 1.910 & 37.363 \\
\hline Lagged 2 months & -0.760 & -4.629 & -0.843 & -2.876 & -0.651 & -8.471 & -0.935 & -18.128 \\
\hline Lagged 3 months & & & 0.111 & 0.346 & & & & \\
\hline Lagged 4 months & & & -0.231 & -0.710 & & & & \\
\hline Lagged 5 months & -0.194 & -1.189 & 0.126 & 0.429 & & & & \\
\hline Lagged 6 months & 0.144 & 1.266 & 0.024 & 0.182 & & & & \\
\hline \multicolumn{9}{|l|}{ Private sector credit growth } \\
\hline Lagged 6 months & & & 0.086 & 1.623 & & & & \\
\hline Lagged 7 months & & & -0.176 & -1.507 & & & & \\
\hline Lagged 8 months & & & 0.087 & 0.689 & & & & \\
\hline Lagged 9 months & & & 0.052 & 0.412 & & & & \\
\hline Lagged 10 months & & & -0.068 & -0.532 & & & & \\
\hline Lagged 11 months & 0.042 & 2.711 & 0.020 & 0.162 & & & & \\
\hline Lagged 12 months & -0.038 & -2.444 & 0.036 & 0.547 & 0.041 & 4.991 & & \\
\hline \multicolumn{9}{|l|}{ Broad money growth } \\
\hline Lagged 6 months & & & -0.157 & -2.169 & & & -0.114 & -2.270 \\
\hline Lagged 7 months & & & 0.407 & 3.164 & 0.145 & 3.775 & 0.210 & 2.211 \\
\hline Lagged 8 months & & & -0.262 & -1.847 & -0.116 & -3.392 & -0.094 & -1.949 \\
\hline Lagged 9 months & & & 0.028 & 0.188 & & & & \\
\hline Lagged 10 months & & & 0.074 & 0.522 & & & & \\
\hline Lagged 11 months & & & -0.072 & -0.558 & & & & \\
\hline Lagged 12 months & & & 0.001 & 0.017 & & & & \\
\hline \multicolumn{9}{|l|}{ Long run coefficient $1 /$} \\
\hline Private sector credit growth & 10.00 & & 3.53 & & 3.47 & & & \\
\hline Broad money growth & & & 7.12 & & 4.85 & & 13.99 & \\
\hline
\end{tabular}

Sources: Pakistani authorities; and own calculations.

1/ Calculated as (1 - sum of coefficients on infllation) / (sum of coefficients on regressor). 
Figure 1. Pakistan: Monetary Developments, 1991/92-2003/04

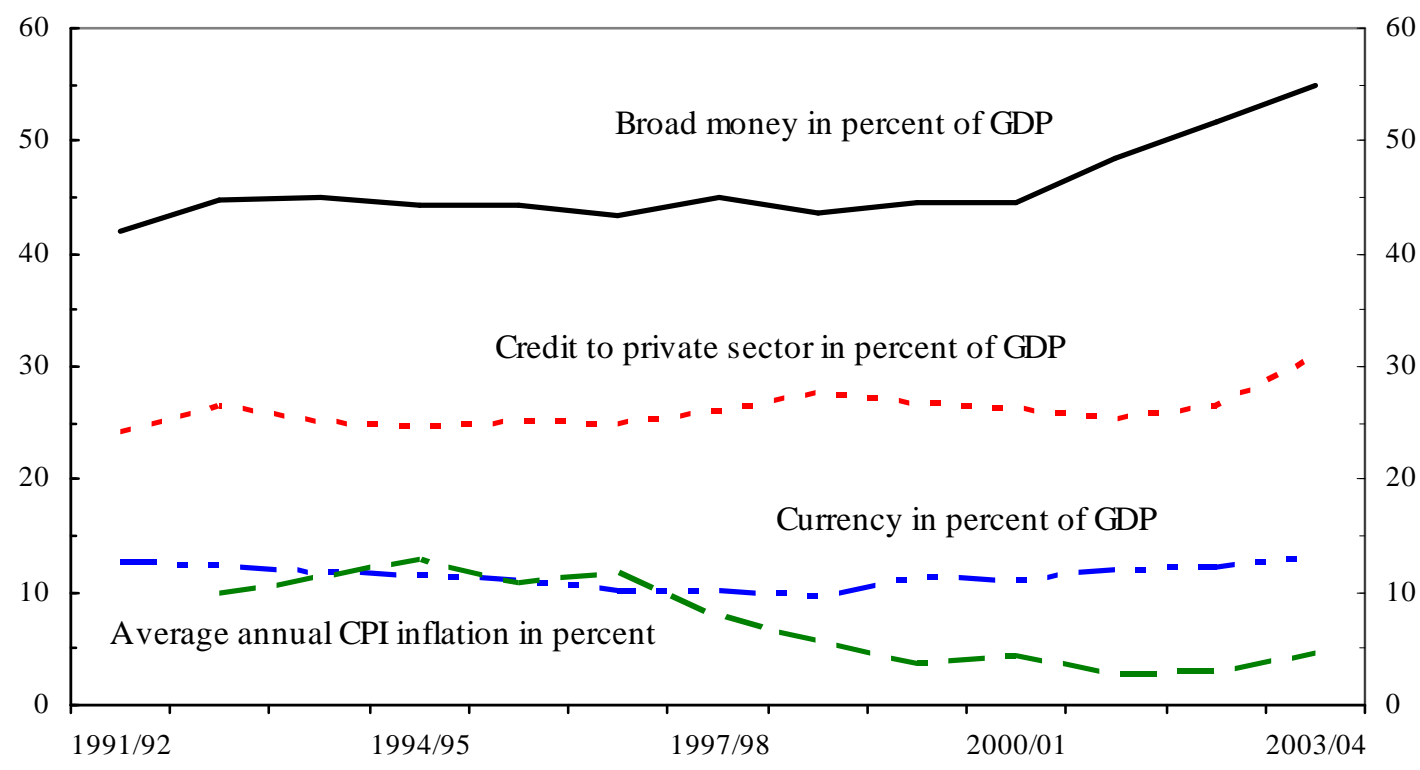

Sources: Pakistani authorities; and own calculations. 
Figure 2. Pakistan: CPI Inflation, 1991-2003

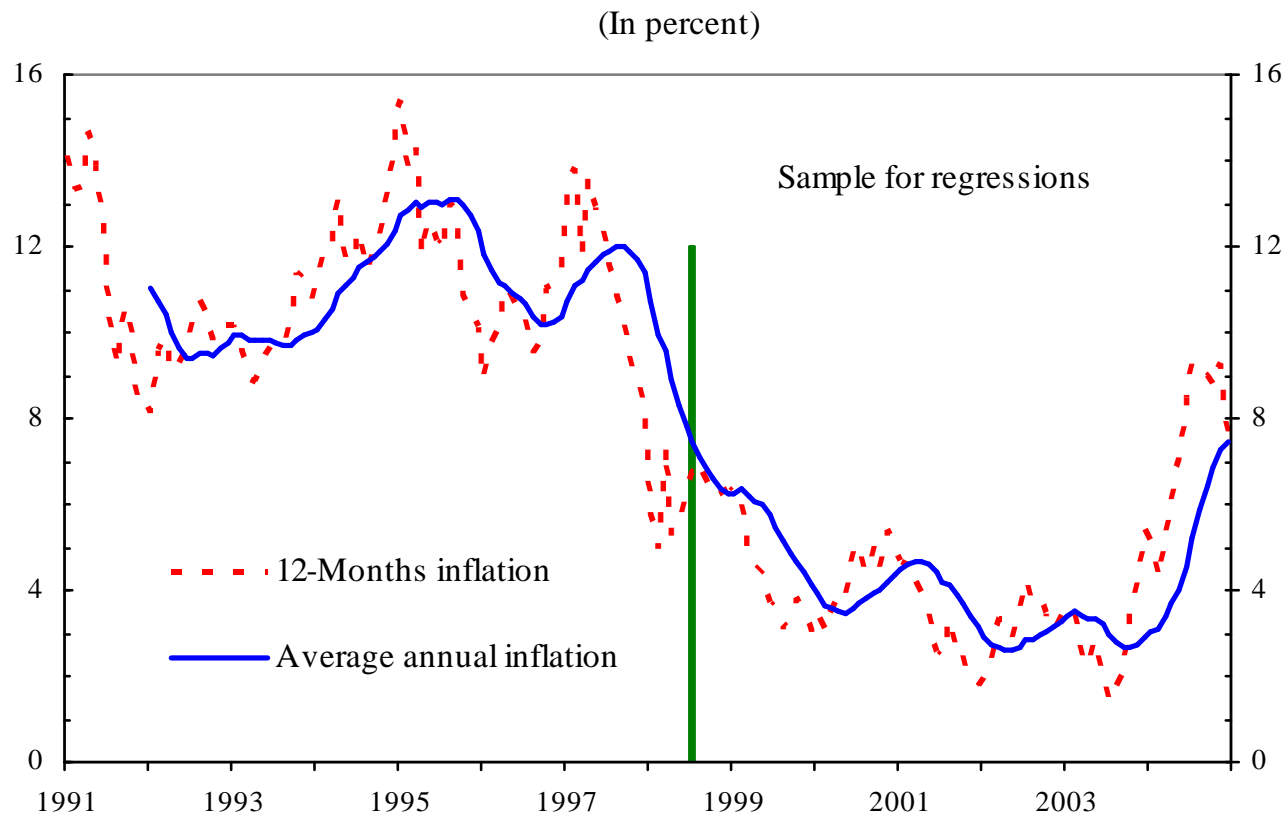

Sources: Pakistani authorities; and own calculations. 
Figure 3. Pakistan: Parameter Instability in the Money Demand Equation with Annual Data, 1978-2004

(a) Constant (log velocity)

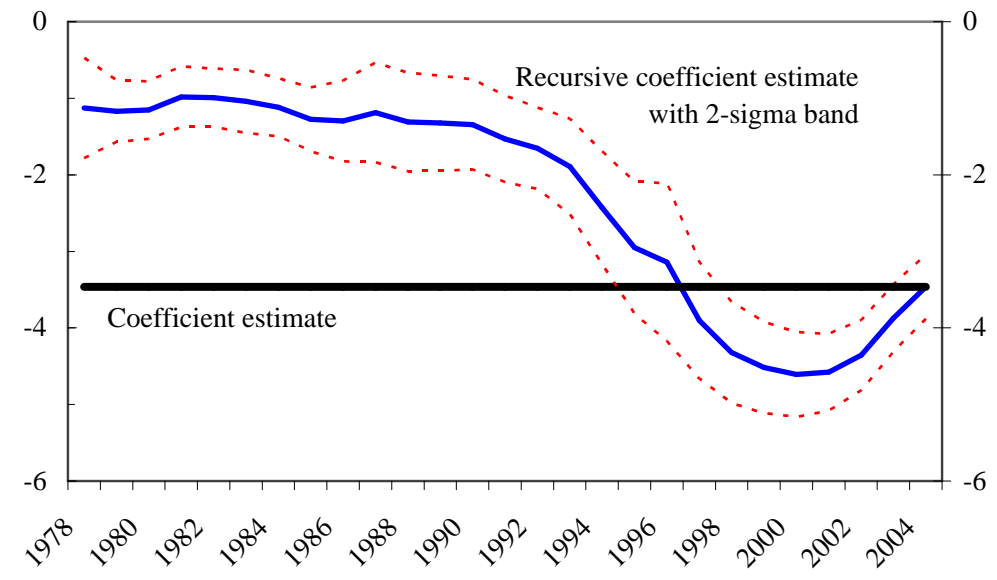

(b) Log of Broad Money (M2)

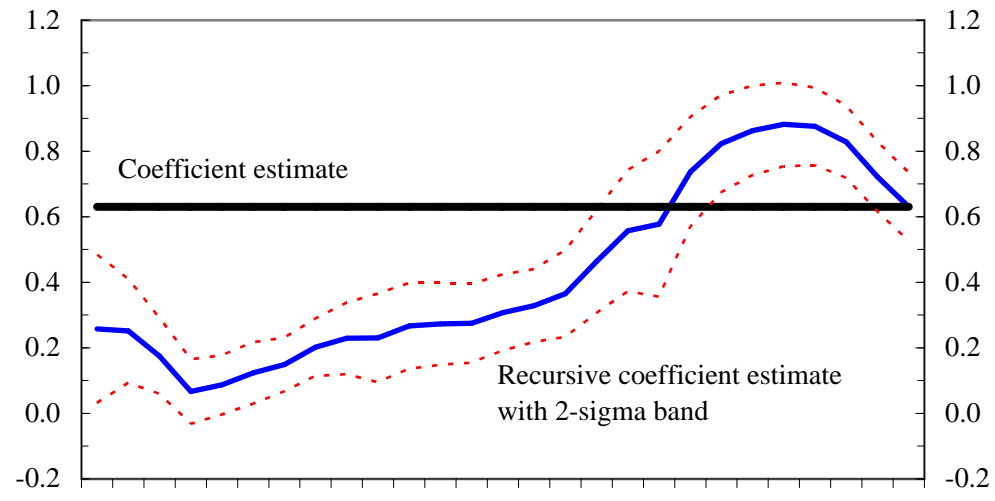

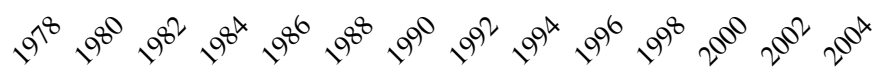


(c) Log of real GDP

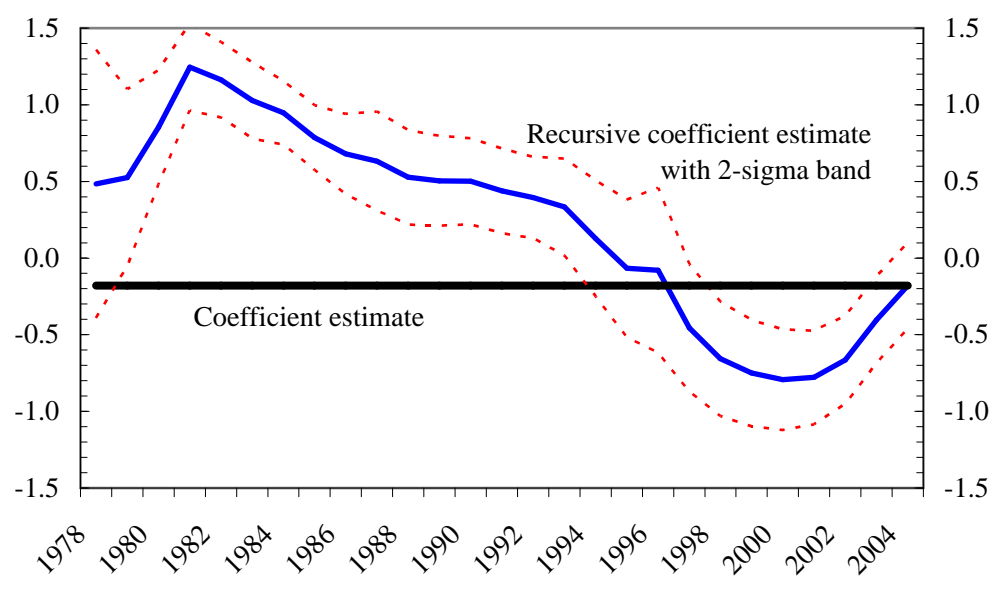

Sources: Pakistani authorities; and own calculations. 
Figure 4. Pakistani: Parameter Instability in the Money Demand Equation with Monthly Data, 1995-2004

(a) Constant (log velocity)

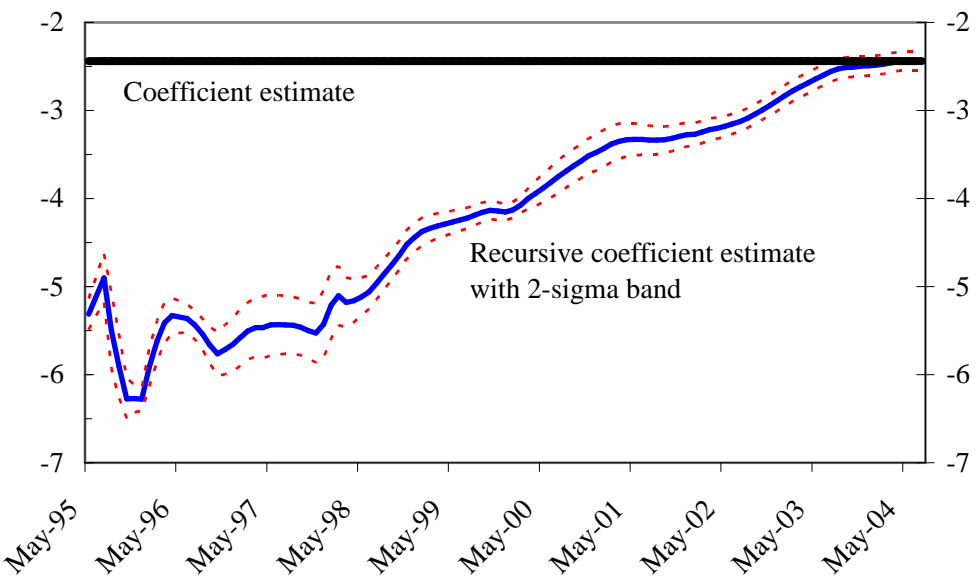

(b) Log Broad Money (M2)

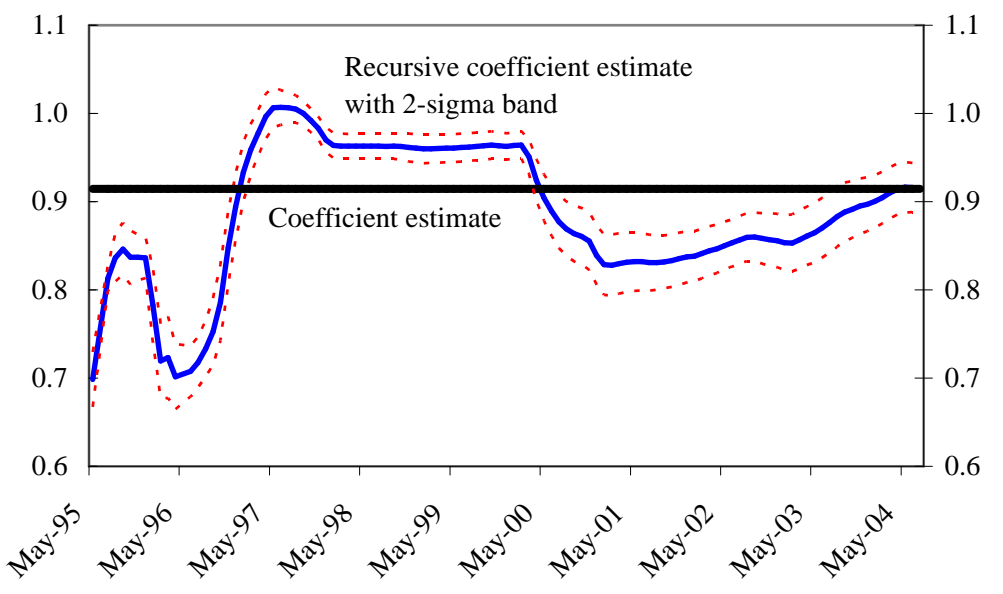


(c) Log real GDP



Sources: Pakistani authorities; and own calculations.

Figure 5. Pakistan: Autocorrelation and Partial Autocorrelation Functions



Sources: Pakistani authorities; and own calculations. 
Figure 6. Pakistan: ARIMA(5,1,1)—Ex-post Forecast, Jul.-Dec. 2004 1/

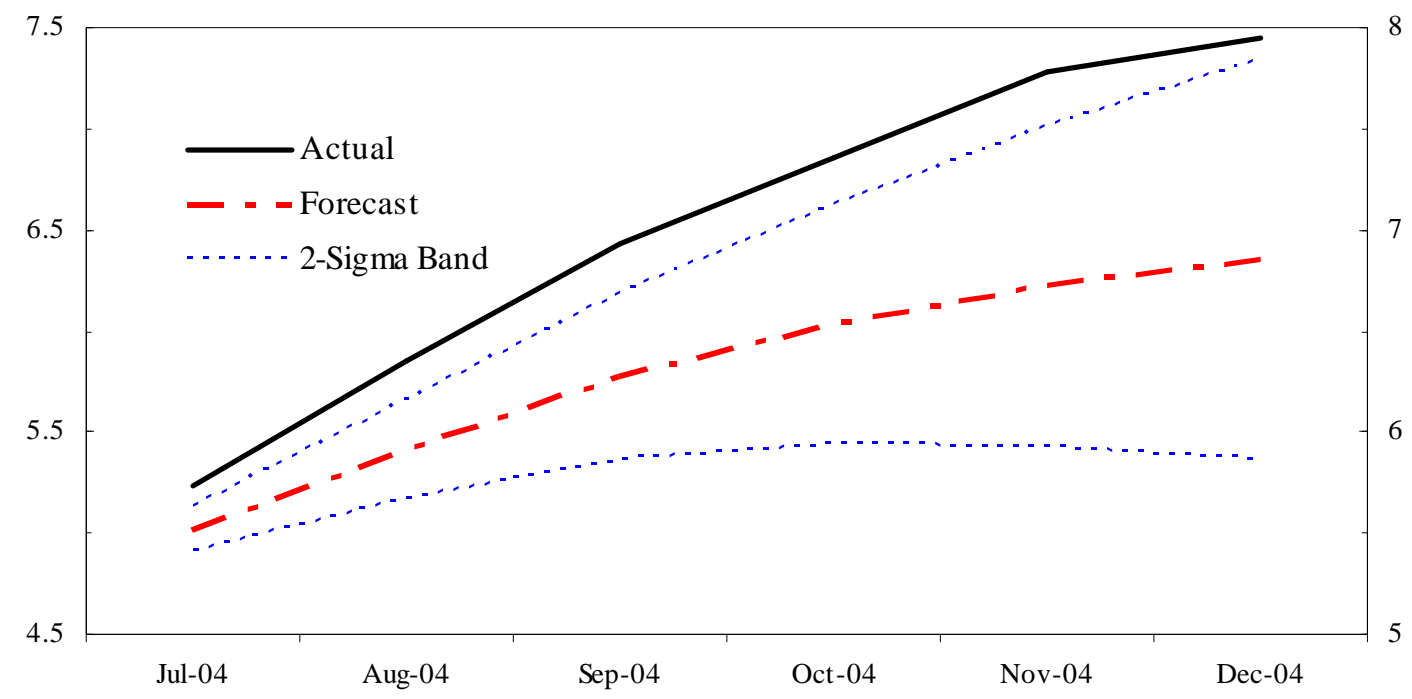

Sources: Pakistani authorities; and own projections.

1/ Forecast based on model for reduced sample through June 2004. 
Figure 7. Pakistan: ARIMA $(5,1,1)$ with Islamic Calendar DummiesEx-post Forecast, Jul.-Oct. 2004 1/

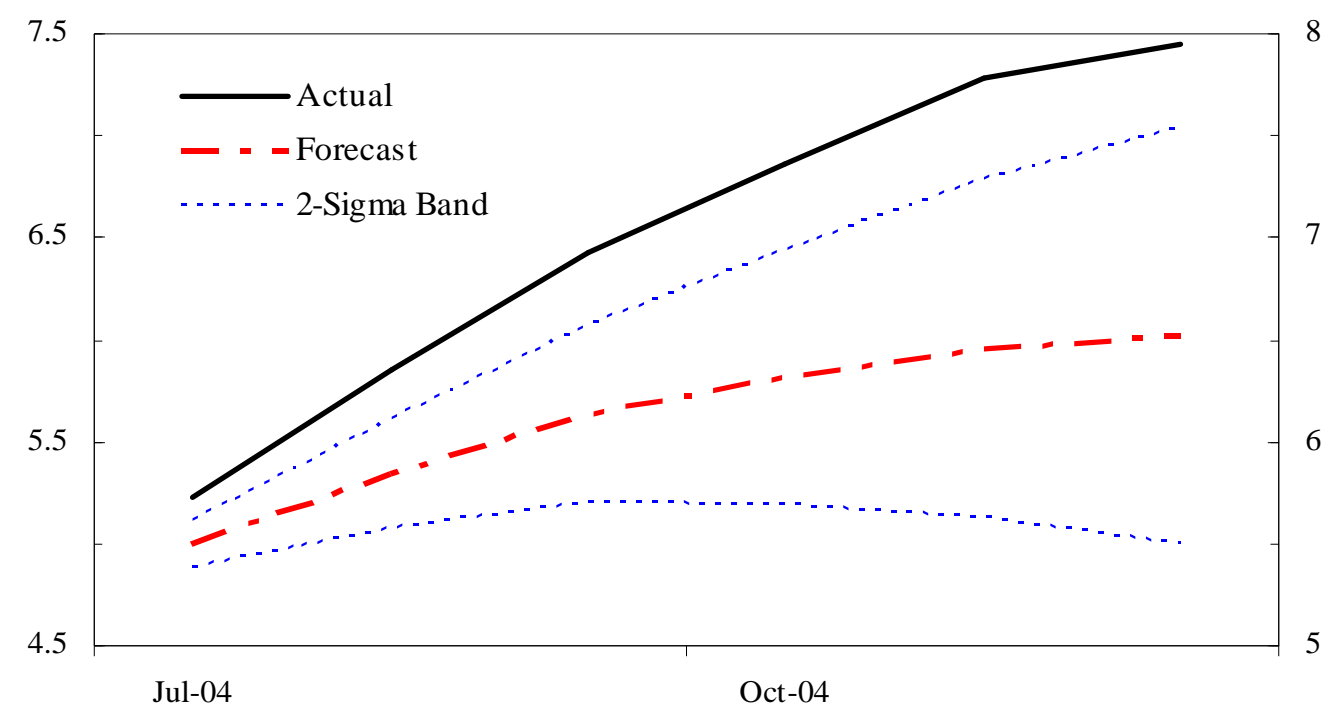

Sources: Pakistani authorities; and own projections.

1/ Forecast based on model for reduced sample through June 2004. 
Figure 8. Pakistan: The Output Gap—Inflation Link, 1998-2004

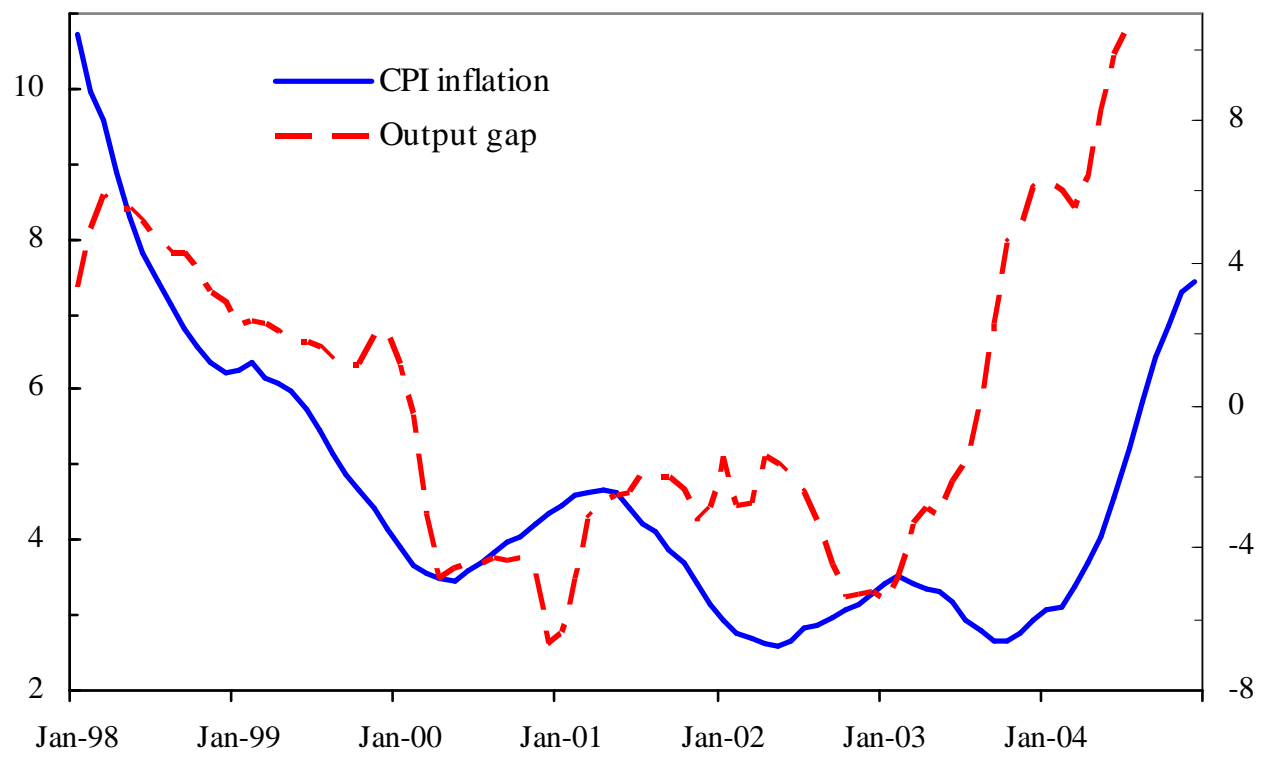

Sources: Pakistani authorities; and own calculations. 
Figure 9. Pakistan: VAR Model—Ex-post Forecast, Jan.-Jun. 2004 1/

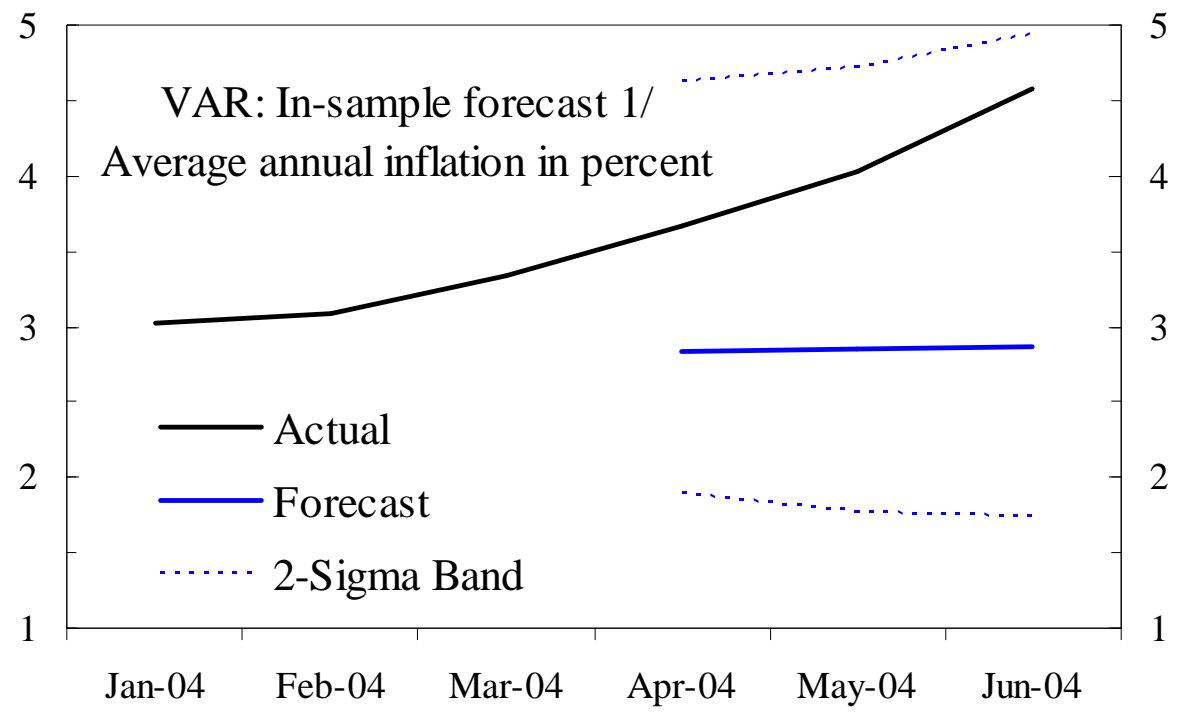

Source: National authorities; and Fund staff calculations.

1/ Forecast based on model for reduced sample through March 2004. 
Figure 10. Pakistan: Leading Indicator Models-Ex-post Forecasts, Jun.-Dec. 2004 1/

(a) Based on Model 1 (Private Sector Credit Growth)

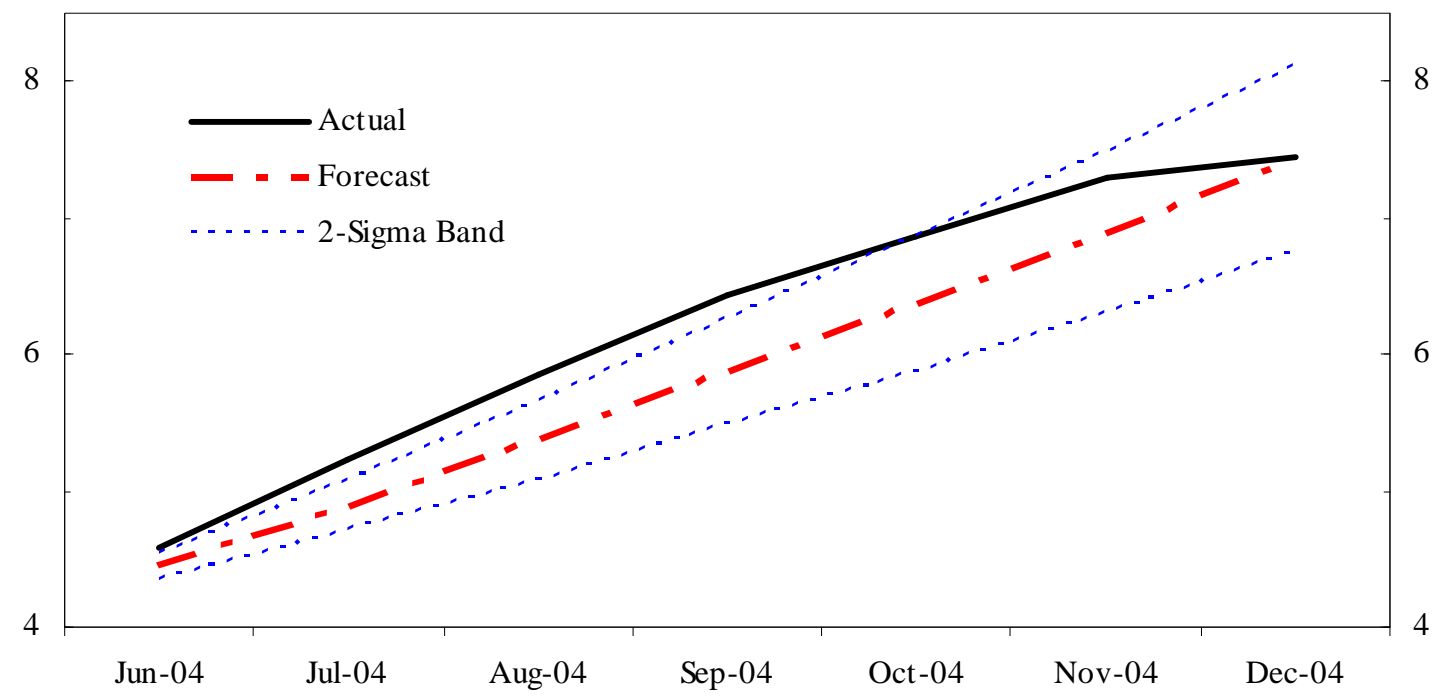

(b) Based on Model 3 (Broad Money and Private Sector Credit Growth)

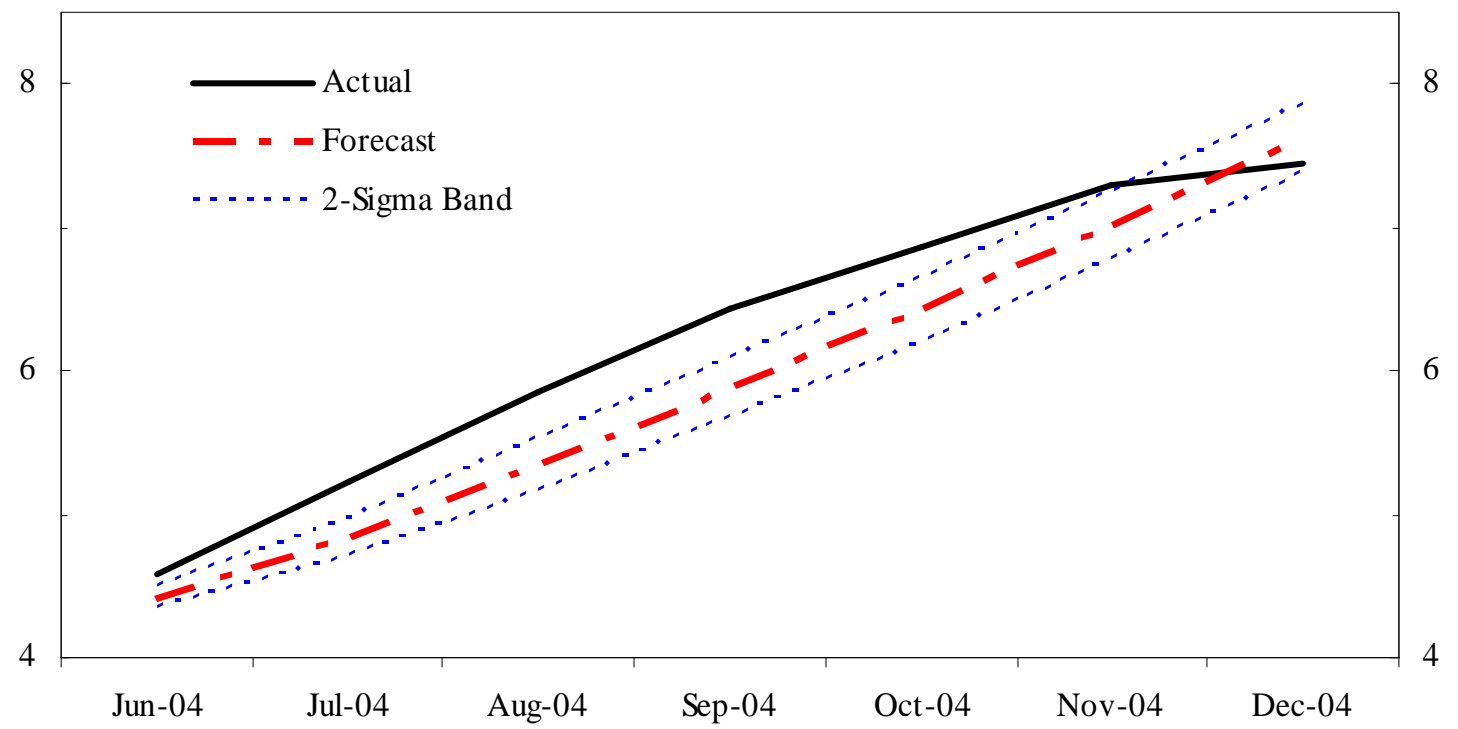

Sources: Pakistani authorities; and own calculations.

1/ Forecast based on model for reduced sample through May 2004. 

Figure 11. Pakistan: Parameter Stability for Leading Indicators Model 1, 2000-04
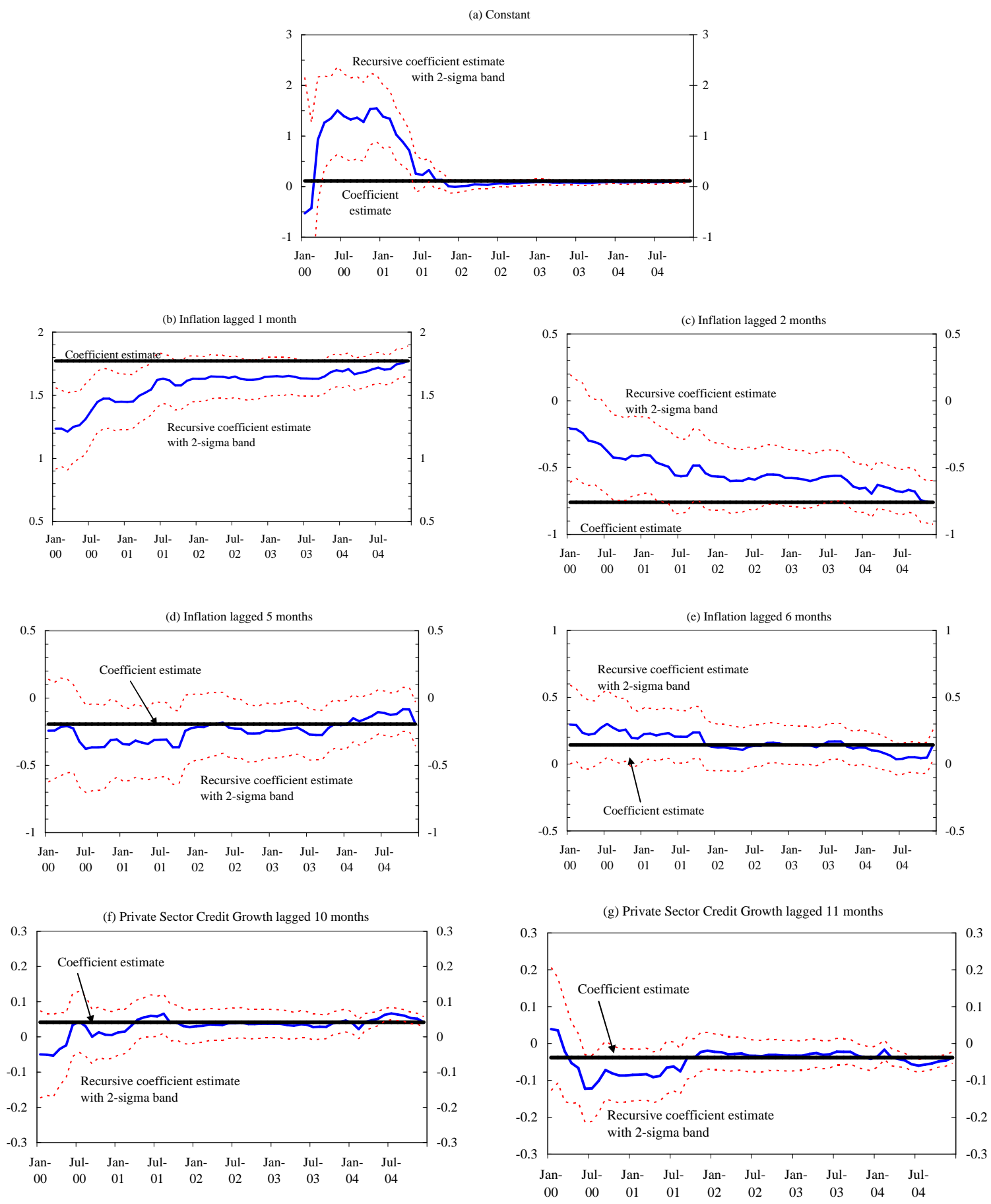
Sources: Pakistani authorities; and own calculations. 
Figure 12. Pakistan: Parameter Stability for Leading Indicators Model 3, 2000-04
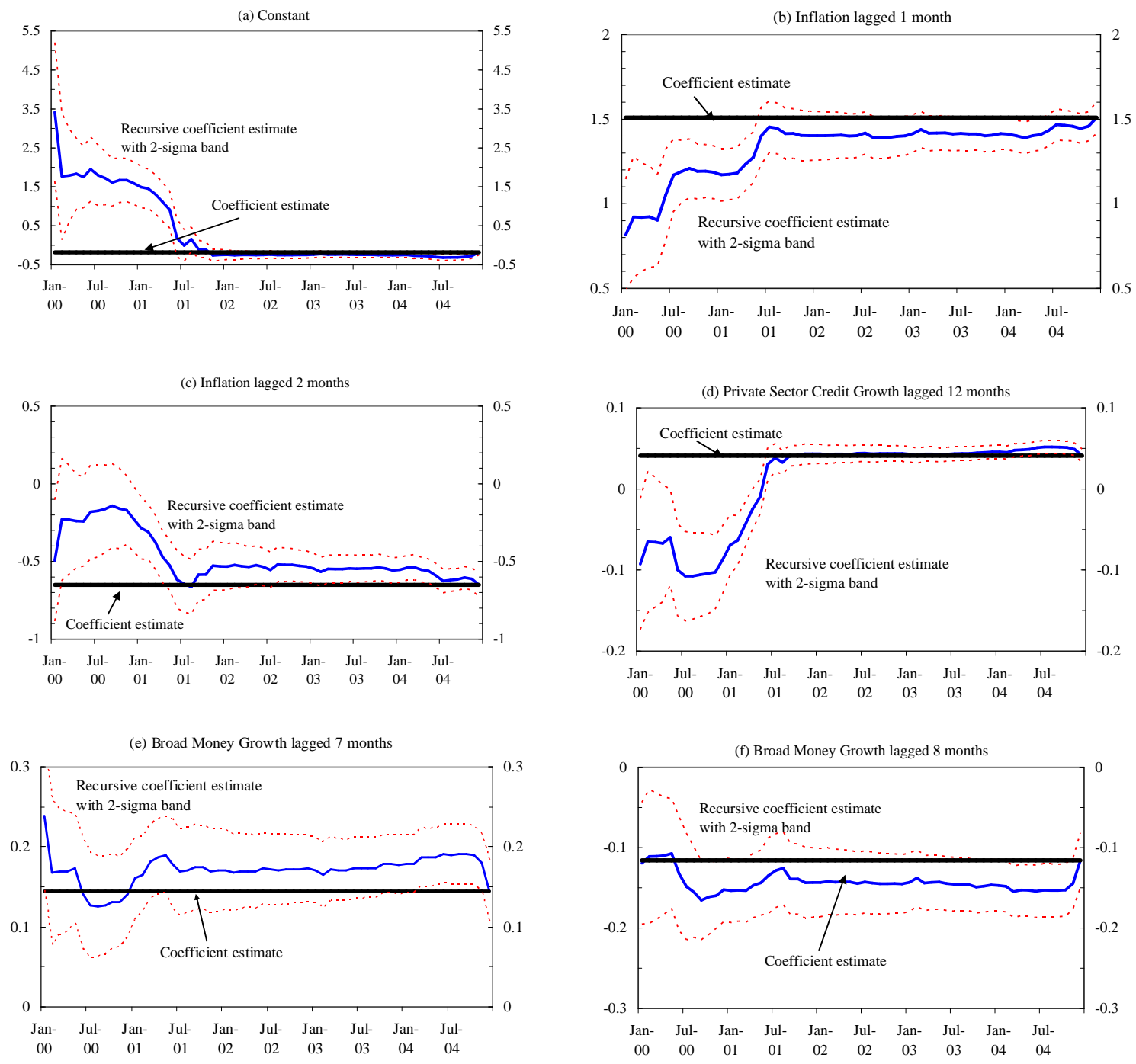

Source: Pakistani authorities; and own calculations.

\section{REFERENCES}

Ahmad, Eatzaz, and Harim Ram (1991) "Foreign Price Shocks and Inflation in Pakistan: A Monetarist Approach," Pakistan Economic and Social Review, Vol. 29, No. 1, pp. 1-20.

Ahmad, Eatzaz, and Muhammad Munirs (2000) "An Analysis of Money Demand in Pakistan," Pakistan Economic and Social Review, Vol. 38, No. 1, pp. 47-67. 
Ahmad, Eatzaz, and Saima Ahmed Ali (1999a) "Relationship Between Exchange Rate and Inflation," Pakistan Economic and Social Review, Vol. 37, No. 2, pp. 139 54.

_ (1999b) "Exchange Rate and Inflation Dynamics," The Pakistan Development Review, Vol. 28, No. 3, pp. 235-51.

Ahmad, Mushtaq, and Ashfaque H. Khan (1990) "A Reexamination of the Stability of the Demand for Money in Pakistan," Journal of Macroeconomics, Vol. 12, No. 2, pp. 307-21.

Arize, A.C. (1994) "A Re-Examination of the Demand for Money in Small Developing Economies," Applied Economics, Vol. 26, pp. 217-28.

Bailliu, Jeannine, Daniel Gracés, and Mark Kruger (2003) "Explaining and Forecasting Inflation in Emerging Markets: The Case of Mexico," Bank of Canada Working Paper 2003-17.

Balke, Nathan, and Kenneth Emery (1994) "Understanding the Price Puzzle" Economic and Financial Policy Review (Fourth Quarter), Federal Reserve Bank of Dallas.

Brissmiss, Sophocles, and Nicholas Magginas (2004) "Forward-Looking Information in VAR Models and the Price Puzzle," Bank of Greece Working Paper No. 10 (February).

Burney, Nadeem A., and Mohammad Akmal (1990) "Expected Inflation Rate, Its Variability, and Desired Real Money Demand in Pakistan: Some Alternative Estimates Using Non-Linear Squares Method," Pakistan Economic and Social Review, Vol. 28, No. 1, pp. 69-88.

Calvo, Guillermo, and Carmen Reinhart (2000) "Fear of Floating," NBER Working Paper 7993 (Cambridge, Massachusetts: National Bureau of Economic Research).

Carare, Alina, and others (2002) "Establishing Initial Conditions in Support of Inflation Targeting," IMF Working Paper 02/102 (Washington: International Monetary Fund).

Chaudhary, Aslam M., and Aurangzaib Khan (1997) "Volatility of Money and Monetary Policy in Pakistan," Pakistan Economic and Social Review, Vol. 15, No. 2, pp. 131-51.

Chaudhary, M. Aslam, and Naved Ahmad (1996) "Sources and Impacts of Inflation in Pakistan," Pakistan Economic and Social Review, Vol. 34, No. 1, pp. 21-39.

Chauvet, Marcelle (2000) "Real Time Leading Indicators of the Brazilian Inflation." Available via the Internet at, http://faculty.ucr.edu/ chauvet/mc.hth.

Choudhri, Ehsan U., and Mohsin S. Khan (2002) "The Exchange Rate and Consumer Prices in Pakistan: Is Rupee Devalution Inflationary?" The Pakistan Development Review, Vol. 41, No. 2, pp. 107-20.

Coe, David, and John Mc Dermott (1997) "Does the Gap Model Work in Asia?" Staff Papers, International Monetary Fund, Vol. 44 (March), pp. 59-80.

Croce, Enzo, and Mohsin S. Khan (2000) "Monetary Regimes and Inflation Targeting," Finance \& Development, Vol. 37, No. 3, pp. 48-51.

Davidson, Russell, and James G. MacKinnon (1993) Estimation and Inference in Econometrics (New York, Oxford: Oxford University Press). 
Dhakal, Dharmendra, and Magda Kandil (1993) "The Inflationary Experience of Six Developing Countries in Asia: An Investigation of Underlying Determinants," Applied Economics, Vol. 25, pp. 413-25.

Estrella, Arturo, and Frederic S. Mishkin (1997) "The Predictive Power of the Term Structure of Interest Rates in Europe and the United States: Implications for the European Central Bank," European Economic Review, Vol. 41, pp. 1375-1401.

Fatás, Antonio, Ilian Mihov, and Andrew K. Rose (2004) "Quantitative Goals for Monetary Policy,” NBER Working Paper 10846 (Cambridge, Massachusetts: National Bureau of Economic Research).

Fischer, Stanley, Ratna Sahay, and Carlos Végh (2002) "Modern Hyper and High Inflations," Journal of Economic Literature, Vol. 40 (September), No. 3, pp. $837-80$.

Giordani, Paolo (2004) "An Alternative Explanation of the Price Puzzle," Journal of Monetary Economics, Vol. 51 (September), No. 6, pp. 1271-96.

Goodhart, Charles, and Boris Hofman (2000) "Do Asset Prices Help to Predict Consumer Price Inflation?" The Manchester School Supplement, pp. 122-140.

Hasan, M. Aynul, S. Ghulam Kadir, and Fakhre Mahmud (1988) "Substitutability of Pakistan's Monetary Assets under Alternative Monetary Aggregates," The Pakistan Development Review, Vol. 27, No. 3, pp. 317-26.

Hausman, Ricardo, U. Panizza, and E. Stein (2000) "Why Do Countries Float the Way They Float?" Journal of Economic Development, Vol. 66, pp. 387-414.

Hendry, David F., and Hans-Martin Krolzig (2004) We Ran One Regression, (London: Oxford University). Available via the Internet at ihttp://Www.nuff.ox.ac.uk/economics/papers/2004/w17/OneReg.pdf

Hossain, Akhtar (1994) "The Search for a Stable Money Demand Function for Pakistan: An Application of the Method of Cointegration," The Pakistan Development Review, Vol. 33, No. 4, pp. 969-83.

Hsing, Yu (1998) "Tests of Changes in the Elasticity of the Demand for M2 and Policy Implications: The Case of Four Asian Countries," Journal of Economic Development, Vol. 23, No. 2, pp. 181-89.

Huq, M.D. Shamsul, and Badiul A. Majumdar (1986) "Stability of the Demand for Money Function: Evidence from a Developing Country," Pakistan Economic and Social Review, Vol. 24, No. 1, pp. 45-55.

Hyder, Zulfiqar, and Sardar Shah (2004) "Exchange Rate Pass-Through to Domestic Prices in Pakistan," State Bank of Pakistan Working Paper No. 5.

International Monetary Fund (2001) Brazil—Selected Issues and Statistical Appendix, IMF Staff Country Report No. 01/10.

(2004) Pakistan-Financial System Stability Assessment, including Reports on the Observance of Standards and Codes on the following topics: Monetary and Financial Policy Transparency, Banking Supervision, and Securities Regulation, IMF Staff Country Report No. 04/215.

Khan, Ashfaque (1982a) "An Analysis of the Demand for Money in Pakistan," Journal of the Institute of Bankers in Pakistan, Vol. 48, pp. 25-34.

(1982b) "Adjustment Mechanism and the Money Demand Function in Pakistan," Pakistan Economic and Social Review, Vol. 20, pp. 36-51. 
Khan, Ashfaque, and Lubna Hasan (1998) "Financial Liberalization, and Economic Development in Pakistan," Economic Development and Cultural Change, Vol. 46, pp. 581-97.

Khan, Ashfaque H. (1982) "The Demand for Money and the Variability of the Rate of Inflation-An Empirical Note," Economics Letters, Vol. 10, pp. 257-61. (1994) "Financial Liberalization and the Demand for Money in Pakistan," The Pakistan Development Review, Vol. 33, No. 4, pp. 997-1,010.

Khan, Ashfaque H., and Bilquees Raza (1989) "The Demand for Money in Pakistan: Quarterly Results 1972-1987," Pakistan Economic and Social Review, Vol. 27, No. 1, pp. 33-48.

Khan, Imran Naveed (1992) "The Demand for Money in Pakistan \& India," Pakistan Economic and Social Review, Vol. 30, No. 2, pp. 181-90.

Leigh, Daniel, and Marco Rossi (2002) "Leading Indicators of Growth and Inflation in Turkey," IMF Working Paper No. 02/231 (Washington: International Monetary Fund).

Marcellino, Massimiliano (2004) "Leading Indicators: What Have We learned," (Forthcoming in: G. Elliot, C.W.J. Granger, and A. Timmermann (eds.), Handbook of Economic Forecasting, Elsevier - North Holland).

Mishkin, Frederic S. (2000) "Inflation Targeting in Emerging Market Countries," NBER Working Paper 7618 (Cambridge, Massachusetts: National Bureau of Economic Research).

Naqvi, Syed Nawab, A.R. Kemal, and Rashid Aziz (1982) The P.I.D.E. Econometric Model of Pakistan's Economy (1959-60 to 1978-79) (Islamabad: Pakistan Institute of Development Economics).

Nisar, Shaheena, and Naheed Aslam (1983) "The Demand for Money and the Term Structure of the Interest Rates in Pakistan," The Pakistan Development Review, Vol. 22, No. 2, pp. 97-116.

Price, Simon, and Anjum Nasim (1999) "Modeling Inflation and the Demand for Money in Pakistan: Cointegration and the Causal Structure," Economic Modeling, Vol. 16, pp. 87-103.

Riazuddin, Riaz, and Mahmood-ul-Hasan Khan (2002) "Detection and Forecasting of Islamic Calendar Effects in Time Series Data," State Bank of Pakistan Working Paper No. 2, (January).

Shamsuddin, Abul F.M., and Richard A. Holmes (1997) "Cointegration Test of the Monetary Theory of Inflation and Forecasting Accuracy of the Univariate and Vector ARMA Models of Inflation," Journal of Economic Studies, Vol. 24, No. 5, pp. 294-306.

Siddiqui, Anjum (1990) "Money and Inflation in Pakistan: Some Tests," Indian Economic Journal, Vol. 38, No. 1, pp. 41-57.

Simone, Francisco Nadal-De (2000) "Forecasting Inflation in Chile Using State-Space and Regime-Switching Models," IMF Working Paper No. 00/162 (Washington: International Monetary Fund).

State Bank of Pakistan (2004) Monetary Policy Statement July-December 2004 (Islamabad). Available via the Internet at hhttp://www.sbp.org.pk $/ \mathrm{m}$ policy/m_policy.pdfi. 
Stock, James H., and Mark W. Watson (1989) "New Indexes of Coincident and Leading Economic Indicators," Olivier Jean Blanchard and Stanley Fischer (eds), NBER Macroeconomics Annual 1989, pp. 351-394 (Cambridge, Massachusetts: MIT Press).

(1999) "Forecasting Inflation," Journal of Monetary Economics, Vol. 44, pp. 293-335.

Sun, Tao (2004) "Forecasting Thailand's Core Inflation," IMF Working Paper No. 04/90 (Washington: International Monetary Fund).

Tariq, Syed Muhammed, and Kent Matthews (1997) "The Demand for Simple-Sum and Divisia Monetary Aggregates for Pakistan: A Cointegration Approach," The Pakistan Development Review, Vol. 36, No. 3, pp. 275-91. 